\title{
Analisis Peran Pemerintahan Dalam Pengendalian Pertumbuhan Penduduk
}

\author{
Diana watik $^{1}$, Farida novitasari ${ }^{2}$ dan Anita Trisiana ${ }^{3}$ \\ ${ }^{1,2}$ Mahasiswa PPkn Universitas Slamet Riyadi Surakarta \\ ${ }^{3}$ Dosen Universitas Slamet Riyadi Surakarta
}

\begin{tabular}{l}
\hline Info Artikel \\
\hline Masuk: 24/01/2022 \\
Revisi: 25/01/2022 \\
Diterima: 27/01/2022 \\
Terbit: 30/01/2022 \\
\\
Keywords: $\quad$ Scientific \\
studies of numbers, \\
processes to minimize \\
population \\
changes in the number of \\
individuals, population \\
comparison. \\
Kata kunci: \\
Studi ilmiah tentang \\
jumlah,proses \\
meminimalisir \\
pertumbuhan penduduk, \\
perubahan jumlah \\
individu, perbandingan \\
populasi.
\end{tabular}

\begin{abstract}
A collection of people to have in an area or a person entitled to occupy an area or

country on the condition that the person must have official letters to people living in the area are called. Demographic studies should be understood to learn about population in the area. Writings on demographic is sort of the population, distribution, and the composition of population. As well as from time to time the change third factor.

For the number of Indonesia largest population in fourth place in the world, with a population of as many as there are 237,6 million people. The larger the population and will bring challenges such as improve the citizens welfare, develop job opportunities, reducing poverty, to develop the quality of education and health, add infrastructure, and community service. In the process reduce the population growth rate introduced steps have been planned before.
\end{abstract}

\section{Abstrak}

Kumpulan masyarakat yang melakukan hubungan dalam suatu daerah atau orang yang berhak menempati suatu daerah atau negara dengan syarat bahwa orang tersebut harus memiliki surat resmi untuk tinggal di wilayah tersebut disebut penduduk. Kajian demografi perlu dipahami untuk mendalami kependudukan di suatu wilayah. Demografi merupakan tulisan tentang kependudukan yang berisi tentang jumlah, persebaran dan komposisi kependudukan. Serta dari waktu ke waktu ketiga faktor tersebut dapat 


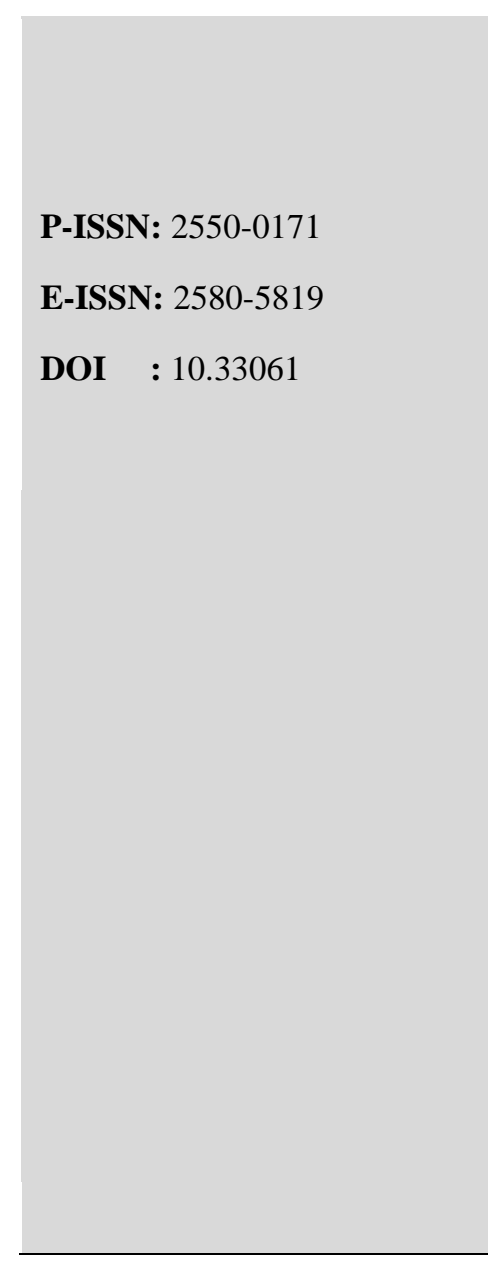

berubah-ubah.

Untuk jumlah penduduk terbanyak di dunia Indonesia menempati posisi keempat, dengan terdapat jumlah penduduk sebanyak 237,6 juta jiwa. Semakin besar jumlah penduduk maka akan membawa tantangan seperti: meningkatkan kesejahteraan rakyat, mengembangkan kesempatan kerja, mengurangi kemiskinan, mengembangkan mutu pendidikan dan kesehatan, menambah infrastruktur, dan pelayanan masyarakat. Dalam proses mengurangi angka pertumbuhan penduduk dilakukan beberapa langkah-langkah yang sudah direncanakan sebelumnya dengan baik untuk dapat berjalan dengan tepat pada saat pelaksanaan, karena pertumbuhan penduduk akan berubah-ubah setiap waktu, dengan demikian pertumbuhan penduduk merupakan perkembangan jumlah penduduk pada suatu daerah dan kurun waktu tertentu dengan membandingkan waktu sebelumnya atau bisa juga diartikan perkembangan jumlah individu dalam suatu kelompok atau populasi dapat dihitung dengan membandingkan jumlah populasi.

\section{PENDAHULUAN}

Mengenai sistem pemerintahan di Indonesia meliputi banyak hal. Tidak hanya berbicara sumber daya alam saja tetapi juga berbicara mengenai sumber daya manusia. Sumber daya manusia dalam ruang ini mengenai pertumbuhan penduduk karena dua hal tersebut memiliki kaitan yang sangat erat apabila salah satunya tidak terkendalikan. Dalam jurnal ini lebih menitikberatkan perihal pertumbuhan penduduk di Indonesia yang menempati posisi keempat terbanyak di dunia. Hal ini menjadi problematika pemerintah sampai saat ini dan menjadi sorotan dalam konteks dunia internasional. Perkembangan pertumbuhan penduduk ini tentu sangat mempengaruhi dan menjadi problem dalam suatu negara guna meningkatkan kesejahteraan. Pertumbuhan penduduk di Indonesia saat ini semakin pesat perkembangannya yang melebihi kapasitas target dari negara

Indonesia. Dalam hal ini, pemerintah harus mampu meningkatkan peforma untuk mengupayakan agar pertumbuhan penduduk terkendali. 
Upaya yang sudah terterapkan di Indonesia meliputi : mengurangi angka pertumbuhan penduduk dengan program $\mathrm{Kb}$, adanya Undang-Undang yang mewajibkan ketetapan usia minimal menikah, dan lain sebagainya yang akan dipaparkan dalam jurnal ini.

Dampak dari pertumbuhan penduduk saat ini lebih berpotensi menjorok ke sisi negatif yaitu : terciptanya banyak pengangguran, tingkat angka kriminalitas semakin tinggi, ekonomi semakin terpuruk, dan bermunculnya pemukiman tidak layak huni karena keterbatasan ekonomi yang tidak memadai untuk memenuhi kebutuhannya. Ini menjadi sorotan pemerintah juga sangat berpengaruh besar terhadap infrastruktur negara Indonesia dalam pemerataan pembangunan.

Berdasarkan latar belakang diatas, penulis tertarik untuk menganalisis peran pemerintahan dalam pengendalian pertumbuhan penduduk dari segi pandang penulis. Faedah dari jurnal ini ialah

agar pembaca dapat memahami akan pentingnya peran pemerintahan dalam menanggulangi pertumbuhan penduduk yang semakin

berkembang pesat

\section{METODE}

Metode yang digunakan dalam penelitian ini adalah metode deskriptif. Menurut sugiyono (2005:21) menyatakan pendapat bahwa suatu metode yang digunakan untuk menggambarkan atau menganalis suatu hasil penelitian tetapi juga tidak digunakan untuk membuat kesimpulan yang lebih luas atau detail disebut metode deskriptif.

Sedangkan menurut pendapat Nazir (1988:

65) menyebutkan bahwa metode deskriptif berhubungan dengan kerja meneliti atau disebut continuity descriptive research secara detail yang dilakukan pada sebuah objek penelitian secara terus menerus. Whitney dan Milholland pada tahun 1930 menggunakan salah satu metode penilitian deskriptif yang sinkron. pada tahun 1930 dalam bukunya berjudul "Colorado State College of Education" yang mempelajari akademis mahasiswa dari status tingkat persiapan. Penelitian dilakukan dalam kurun waktu empat tahun, dengan menjelajahi status akademis sejak tingkat persiapan sampai dengan lulus 
sarjana muda. 


\section{PEMBAHASAN}

\section{Definisi Kependudukan}

Menurut P.N.H Simanjutak mengatakan bahwa jika penduduk itu orang yang bertempat tinggal ataupun yang sedang berdomisili di suatu negara. Definisi penduduk ditinjau dari segi pandang penulis merupakan perkumpulan sejumlah orang yang menempati suatu negara dan terikat aturan-aturan yang ada dalam suatu negara. Dikatakan penduduk Indonesia apabila orang tersebut memiliki tanda pengenal seperti KTP,KK,Akte yang berdomisili dan berkewarganegaraan Indonesia.

Perubahan populasi sewaktu- waktu, dan bisa dihitung sebagai perubahan dalam jumlah individu dalam sebuah populasi memakai "per waktu unit" untuk pengukuran merupakan definisi pertumbuhan penduduk. Sebutan pertumbuhan penduduk merujuk pada semua spesies, tetapi selalu mengarah pada manusia, dan sering dipakai secara informal untuk sebutan demografi nilai pertumbuhan penduduk, dan dipakai untuk merujuk pada pertumbuhan penduduk dunia.

Definisi perkembangan penduduk yaitu perubahan jumlah penduduk dalam kurun waktu tertentu baik semakin bertambah maupun berkurang. Ini dapat menjadi indikator untuk mengetahui seberapa besar perubahan pertumbuhan penduduk 


\section{Indikator yang dapat mempengaruhi pertumbuhan penduduk}

a. Kelahiran

Indikator ini bisa dipengaruhi oleh sejumlah faktor. Antara lain : di usia muda banyak penduduk yang menikah, dan belum melaksanakan program keluarga berencana yang sangat mempengaruhi pertumbuhan dan perkembangan penduduk secara pesat. Pemerintah saat ini sudah melaksanakan program minimal usia menikah dan program BKKBN untuk meminimalisir angka pertumbuhan penduduk.

\section{b. Kematian}

Hilangnya kehidupan manusia secara permanen dan sifatnya dapat mengurangi jumlah penduduk disebut kematian. Indikator ini memiliki ikatan kuat karena jika semakin tinggi angka kematian maka semakin rendah angka jumlah penduduk.

c. Migrasi

Sekumpulan orang yang ingin berpindah tempat dari suatu wilayah ke wilayah yang lain yang mempunyai tujuan untuk mencari tempat tinggal. Dengan ini, menyebabkan meningkatnya populasi penduduk pada suatu negara. Migrasi ada dua yaitu : migrasi keluar dan migrasi masuk.

Migrasi keluar (emigrasi) : berpindahnya penduduk ke wilayah yang masih berada di wilayah Indonesia.

Sedangkan migrasi masuk (imigrasi) : berpindahnya penduduk ke wilayah yang berada diluar dari Indonesia. 


\section{Kependudukan di Indonesia}

Menurut teori Thomas Robert Malthus, seorang pendeta Inggris hidup pada tahun 1766 hingga tahun 1834. Karangannya yang berjudul "Essai On Principle of Populations as it Affect the Future Improvement of society, with Remarks on the Speculation of Mr. Godwin, M. Condorcet, and Other Writers", dikemukakan oleh Thomas Robert pada tahun 1834 bahwa penduduk ( seperti binatang dan tumbuhtunbuhan) jika pembatasan ditiadakan, maka akan pertumbuhannya akan berkembang pesat dan permukaan bumi akan dipenuhi (Mantra, 2003:50).

Ahli biologi di Universitas Standford yang bernama Paul, menulis buku pada tahun 1871 berjudul "The Population Bomb" lalu di revisi menjadi "The Population Explotion" dan Meadow melengkapi melalui “The Limit to Growth" pada tahun 1972, ia mengkaitkan antara variabel lingkungan (sumber daya alam, produksi pertanian, produksi industri, dan penduduk) dengan populasi. Meskipun begitu, manusia harus menjaga dan mengelola alam dengan baik agar terhindar bencana alam

Ada beberapa cara yang sudah diterapkan pemerintah Indonesia antara lain :

\section{a. Program BKKBN}

Program pemerintah untuk mencanangkan progam keluarga berencana atau KB.

Program ini ditujukan kepada penduduk yang sudah menikah dengan embel-embel "Dua Anak Lebih Baik". Guna untuk mengurangi pertumbuhan penduduk agar tercipta kemerataan penduduk di wilayah tertentu.

b. Program usia minimal menikah

Banyak sekali kasus pernikahan dini di berbagai daerah yang akan mengakibatkan dapat menekankan angka pertumbuhan penduduk dan mengatasi kepadatan 
penduduk serta pemerintah membuat dan menetapkan UU yang mengatur tentang batas minimal usia untuk menikah.

c. Meratakan pertumbuhan kependudukan

Didaerah-daerah pada saat ini pekerjaan adalah yang umum dialami oleh masyarakat untuk perpindah kerja ke wilayah lain karena beberapa lapangan kerja.Hal ini banyak sekali masyarakat daerah ingin mencari pekerjaan yang layak.

d. Meningkatkan pelayan dalam bidang pendidikan Banyak pendidikan yang berkaitan untuk mengendalikan pertumbuhan penduduk.

Ditemukannya pekerjaan yang tidak memiliki banyak keahlian dikarenakan tidak meneruskan pendidikan ke jenjang yang lebih tinggi serta memilih fokus untuk menikah di usia muda.

e. Meningkatkan wajib belajar. Pendidikan adalah pembelajaran, pengetahuan, keterampilan, dan kebiasaan sekelompok orang yang diturunkan melalui pengajaran, pelatihan, atau penelitian. Pengalaman masyarakat yang dimiliki menjadi dampak negatif pada suatu pekerjaan.

4. Perubahan jumlah penduduk

Perubahan menurut penulis adalah suatu hal dalam kurun waktu tertentu mengalami "ada yang berbeda" baik menuju yang lebih baik maupun lebih buruk. Dan perubahan menurut ahli Kingsley Davis mengatakan bahwa wujud perubahan yang terjadi pada struktur dan fungsi suatu masyarakat disebut perubahan sosial Peledakan penduduk menurut Kamus Besar Bahasa Indonesia adalah pertambahan penduduk yang sangat besar karena angka kelahiran lebih tinggi dari pada angka kematian. Perubahan penduduk bisa saja terjadi dengan adanya peledakan penduduk juga bisa kekurangan penduduk. Untuk perubahan jumlah penduduk dapat diketahui dengan metode sensus penduduk.

Pengertian dari sensus penduduk itu sendiri ialah menghitung cacah jiwa yang ada pada suatu wilayah. 


\section{PENUTUP}

\section{Kesimpulan}

Perubahan populasi yang dapat diperkirakan sensus penduduk adalah pengertian dari pertumbuhan penduduk. Hal ini dapat diartikan bahwa pertumbuhan Perubahan populasi yang dapat diperkirakan dalam sensus penduduk adalah pengertian dari pertumbuhan penduduk semakin banyak semakin tingginya pengangguran di Indonesia. Berdasarkan penjelasan diatas dapat ditarik kesimpulan bahwa pertumbuhan penduduk dipengaruhi oleh angka kelahiran (natalitas), kematian (mortalitas), dan perpindahan penduduk (migrasi) juga ada beberapa pendapat para ahli mengenai perkembangan jumlah penduduk. Untuk laju perkembangan pertumbuhan penduduk atau perkembangan pertumbuhan jumlah penduduk di suatu wilayah tertentu setiap tahunnya. Terdapat faktor penunjang seperti menikah di usia muda, adanya program BKKBN, dan faktor pendidikan sejak dini. Diatas sudah dijelaskan bagaimana peran pemerintah dalam meminimalisir adanya ledakan jumlah penduduk di Indonesia. Separuh penduduk Indonesia di dominasi dua suku terbesar di pulau Jawa yaitu suku Sunda dan suku Jawa yang mengakibatkan populasi penduduk di Jawa semakin banyak Perbandingan populasi merupakan rasio perbandingan misalnya antar gender laki-laki dengan perempuan di suatu wilayah guna untuk memperhitungkan antara jumlah penduduk laki-laki dengan jumlah penduduk perempuan pada suatu wilayah negara. Sayangnya, terdapat ketimpangan populasi yang cukup tinggi yang mengakibatkan sentrimen negatif sebagian penduduk Indonesia misalnya tingkat pengangguran lebih tinggi, angka kriminalitas semakin meningkat, dan timbul banyak pemukiman yang tidak layak huni seperti banyak pemukiman di pinggir sungai dan adanya rumah susun (rusun). 


\section{Saran}

Pertumbuhan penduduk dapat berubah-ubah dalam kurun waktu tertentu tergantung pada indikator-indikator yang mempengaruhinya seperti yang sudah dijelaskan pada jurnal ini. Ada baiknya jika pemerintah menaruh perhatian lebih khusus dalam mengendalikan dan meminimalisir jumlah pertumbuhan penduduk. Hal ini dapat digunakan dengan cara pendekatan untuk menanggulangi terjadinya kepadatan penduduk di suatu wilayah tertentu misalnya membatasi pemukiman yang ada di pinggiran sungai maupun pinggir jalan rel kereta api sehingga dapat mengakibatkan terganggunya perencanaan tata ruang di wilayah tersebut yang selama ini terus menerus terjadi. Pemerintah indonesia dalam perencanaan tata kelola untuk membangun mekanisme yang melibatkan pemerintah daerah melalui bersama mengatasi pembangunan yang berlanjutan 


\section{DAFTAR PUSTAKA}

fah, Nunuy Nur. (2014). The Effect of The Implementation of Government Internal Control System (GICS) On The Quality of Financial Reporting of The Local Government and Its Impact On The Principles of Good Government : A Research In District, City, and Provincial Government In South Sumatera.

Anangkota, Muliadi. (2013). Klarifikasi Sistem Pemerintahan Perspektif Pemerintahan Modern Kekinian.

Busroh, Abu Daud. 2010. Ilmu Negara, Jakarta : Buumi Aksara.

Desriadi. (2016) Demokrasi dan Pemerintahan, Riau.

Kansil, Drs, C. S. T, SH, Hukum Antar Tata Pemerintahan

Indonesia, Jakarta : Erlangga, 1987.

Isa, Aminu Muhammad. (2014). Dimension of IFRS Transition Roadmap's Information Content In LDCs:A Case of Nigeria.

Kansil, C.S.T. 1991. Pengantar Hukum Kesehatan Indoneisa, Jakarta : Rineka Cipta.

Kurde, Arfawie Nukthoh. 2005. Telaah Kritis Teori Negara Hukum. Yogyakarta : Pustaka Pelajar, 2005.

Sroedji, Moch. 2013. Demokrasi dan Sistem Pemerintahan.

Santoso, M.Agus. (2013). Perkembangan Konstitusi Di Indonesia.

Yurniwati, Afdhal Rizaldi. (2015). Control Environment Analysis at Government Internal Control System: Indonesia 
